UDC 624.1

DOI: https://doi.org/10.26642/tn-2019-1(83)-262-269

V.V. Vapnichna, Ph. D

N.A. Shevchuk, Ph. D

National Technical University of Ukraine «Igor Sikorsky Kyiv Polytechnic Institute»

\title{
Determination of soil summary pressure on basket walls
}

The analysis of modern design methods for mounting the pits side indicates the difficulty in predicting the magnitude and distribution of the load on supporting flexible walls. Existing normative methods for calculating supporting structures of foundation pits are generally aimed at ensuring their durability and stability. Using these methods, load on the fence, depending on the strength parameters of the soil, determine shifts, bending moments, transverse and longitudinal forces, and calculate the parameters of the fence it is necessary to ensure the strength of the structure. The necessary depth of its foundation determines the condition of the stability of the fence. The generalization of knowledge in this area, as well as the development of a mathematical model for numerical implementation of the considered problem, will increase the level of rational consolidation of deep pits.

In the course of the study, a mathematical model was developed from the following types of mounting: drill piles, tangent drill piles, "Larsen" tufts, monolithic "wall in the ground" in the GeoWall software complex, which is widely used to calculate the strength and stability of supporting walls of foundation pits of different type. According to the results of computer simulation, the largest horizontal deformations are inherent to a type-L4-type tongue mount, which is about $8 \mathrm{~cm}$. The maximum deformation patterns of the drill piles and tangent drill piles are quite similar, respectively; they are 4.1 and $3.9 \mathrm{~cm}$. Therefore, for further the study was adopted as a monolithic "wall in the soil", as the depth of the development of the pit horizontal deformations increase in the range from $0.3 \mathrm{~cm}$ to the maximum displacement of $2.6 \mathrm{~cm}$. Maximum vertical displacement of compression is about $0.5 \mathrm{~cm}$.

Keywords: flexible walls; foundation pit; calculation scheme; load distribution; active and passive soil pressure.

Introduction. This work considers the determination of soil lateral pressure on flexible retaining walls. The value of the horizontal pressure of the soil on the retaining wall depends on the angle of the surface of the soil to the horizon, its physical and mechanical properties, the frictional forces on the contact surface of the "retaining wall - the soil massif", as well as the magnitude of the horizontal displacements of the structure.

The total pressure acting on the fence is determined by the sum of the effective pressure caused by the stressdeformed state of the skeleton of the soil, and the pore pressure of water.

The pressure of the soil on the enclosure surface depends on many factors [1]:

- method and sequence of soil filling;

- deposition and displacement of the wall under the influence of their own weight and pressure of the soil;

- natural and artificial torque;

- physical and mechanical properties of the soil;

- random or systematic soil shock;

- type of supporting structure.

Analysis of research and publications. The main feature in designing flexible wall structures is to determine the effect of soil pressure and its interaction with the design.

Namely active, passive soil pressure and additional reactive loads.

The existing theories aimed at determining the pressure of the soil, allow you to solve with varying degrees of accuracy delivered task. Proposed in 1776, the Coulomb theory, based on the boundary equilibrium of the shift prisms soil, limited by straight planes. Indeed, the assumption of a boundary equilibrium shows that the appearance of these surfaces is curvilinear. However, the magnitude of active pressure of the soil on vertical or near vertical tight, smooth and rough wall by Coulomb and the exact technique differ by $2-3 \%$ which certainly can be considered a permissible camping resulting from the engineering point of view [1-2].

Of great importance is the passive and soil pressure, the value of which depends on the degree of soil grafting from the surface of the structure. Consideration of friction soil using dependencies Theories Coulomb's at the corners of the occurrence $\varphi=15-20^{\circ}$ gives a significant error, increasing the rate. More precise results are given in the theory proposed by S.V. Sokolovskyi, which is based on the general theory of the boundary stress state of the friable medium. There are various interpretations of this theory, including the well-known graphic form of S.S. Halushkevych [1-2].

There are the following types of lateral pressure of soil [3]: 
Active pressure $\left(\sigma_{\mathrm{a}}\right)$ is force influence of the soil on the enclosing structures in the state of the boundary equilibrium, corresponding to the stage of formation of the displacement surface, in which the structure moves in the direction of the action of pressure. (Fig. 1, a).

Passive pressure $\left(\sigma_{\mathrm{p}}\right)$, this pressure in the soil, caused by the movement of the retaining wall on the side of the fill, which leads to pushing and increasing the level of fill. (Fig. 1, в).

Relaxation pressure $\left(\sigma_{0}\right)$, so-called natural (natural), which operates in the case when the wall (protective surface) is immobile or relative movements of the soil and small structures (Fig. 1, б);

Additional reactive pressure $\left(\sigma_{\mathrm{r}}\right)$, is formed when the structure moves towards the soil (in the direction opposite to the pressure), but does not cause "soil gravity". The greatest value for a supporting structure is passive pressure, the smallest - active.
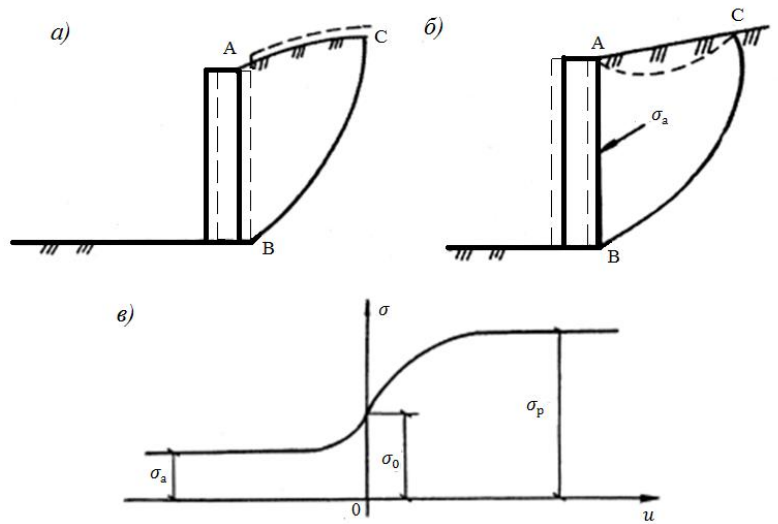

Fig. 1. Circuits to types of ground pressure: a) active pressure; б) resting pressure; 6 ) change in the pressure of the soil depending on the movement of the wall

The relation between the considered forces looks like this:

$\sigma_{\mathrm{a}}<\sigma_{0}<\sigma_{r}<\sigma_{\mathrm{p}}$

In the calculations, active soil pressure is taken into account as an external load on the stability of structures on the shifts and strength of flexible structures. Passive pressure is taken into account as the limiting reactive force for the stability and strength of structures for which horizontal movements are permissible. The side pressure of the ground in a state of rest is taken into account when the strength of the angular and fortress retaining walls, the massive walls of the chambers of the sluice chambers, docks, etc. are established [3].

The aim of the work is to synthesize knowledge in this field, as well as to develop a mathematical model for numerical implementation of the considered problem, analysis of deformations with increasing depth of the pit.

Research results. To calculate the retaining wall, it is necessary to know the full pressure on any part of the design from the surfaces and the ground to the design mark. Considering an infinitely long wall with identical conditions along its length, we present the problem to the plane model. In this case, the supporting wall is considered in the length of $1 \mathrm{~m}$. The pressure of the soil, which is per unit of wall height in the thickness of $1 \mathrm{~m}$, is called intensive pressure, which is considered to be distributed by the height of the wall according to the linear law.

In some cases, the pore pressure of water on the fence is determined by the pressure of the column of liquid, which is above the calculated section. In the case of a foundation pit in non-water-saturated soils, the resultant soil pressure on the fence will be fully determined by effective pressure. To substantiate the side pressure $\sigma_{\mathrm{x}}$ soil on the supporting structure, we consider the simplest calculation scheme presented on (Fig. 2).

The pressure of the soil on a stationary wall $\left(\mathrm{u}_{\mathrm{x}}=0\right)$ is called pressure in a state of rest and is determined by the expression:

$\sigma_{0}(z)=\left.\sigma_{x}\left(z, u_{x}\right)\right|_{u_{x}=0}=\lambda_{0} \gamma z$

Where, $\lambda_{0}$ is the coefficient of the side pressure of the ground in a state of rest;

$z$ is distance from the soil surface to the considered point; $\gamma$ is specific gravity of the soil.

At significant displacement of the wall from the ground at depth $z$, the active pressure on the fence $\sigma_{\mathrm{a}}$ is realized, which corresponds to the minimum pressure value. Passive pressure $\sigma_{p}$, is realized at significant displacement of the wall on the soil. In the absence of a load on the soil surface, the expressions for determining the active and passive pressures have the form:

$\sigma_{a}(z)=\lambda_{a} \gamma z-c \lambda_{a c}$

$\sigma_{p}(z)=\lambda_{p} \gamma z-c \lambda_{p c}$

$\lambda_{a c}-$ coefficient of account of the influence of soil connectivity on active pressure;

$\lambda_{p c}-$ coefficient of account of the influence of soil connectivity on passive pressure;

$\lambda_{a}-$ coefficient of active soil pressure; $\lambda_{p}-$ to the passive pressure of the soil; $c$ - specific gravity of the soil. 


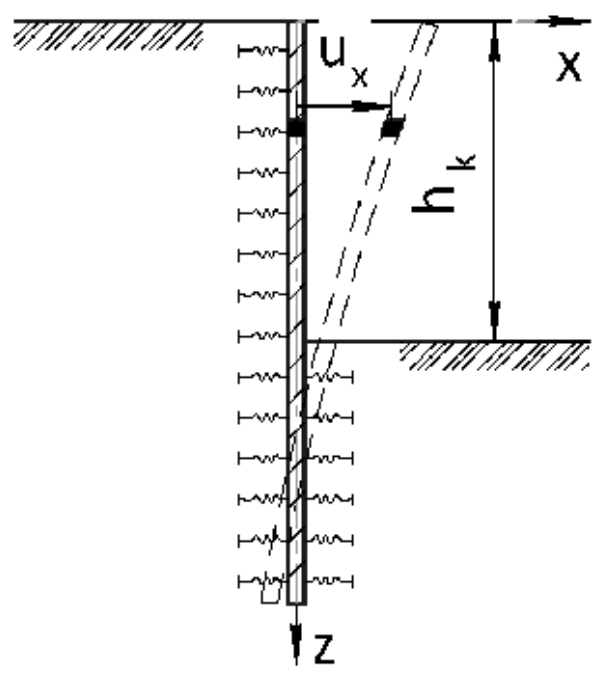

Fig. 2. Scheme of flexible retaining wall, where $x_{z}$ is the coordinate system, $h_{k}$ is the depth of the pit, $u_{x}$ is horizontal movement of the mount

The active and effective pressure of the soil on the fence is marginal value of the pressure in, that is, the effective pressure is always in the range:

$\sigma_{a}(z) \leq \sigma_{x}\left(z, u_{x}\right) \leq \sigma_{p}(z)$

The dependence of the effective horizontal pressure of the soil on the supporting structure is in the range $u_{x} \in$ $\left(u_{\mathrm{p}}, u_{\mathrm{a}}\right)$, Fig. 3 [3].

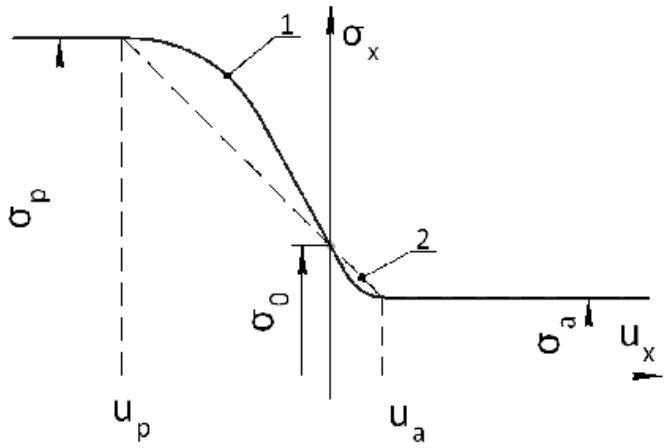

Fig. 3. Graph of the pressure of soil on the retaining wall of $i$ displacement: 1 -actual pressure; 2 -approximation of partial linear function

The function of changing the pressure value $\sigma_{\mathrm{x}}$ at some depth $\mathrm{z}$ from displacements can be represented as follows:

$$
\sigma_{x}\left(u_{x}\right)=\left\{\begin{array}{cc}
\sigma_{p}, & u_{x} \leq u_{p} \\
f\left(u_{x}\right), & u_{p}<u_{x}<u_{a} \\
\sigma_{a}, & u_{a} \leq u_{x}
\end{array}\right.
$$

If you separately consider the resulting pressure on the fence before laying $f\left(u_{x}\right)$ can be replaced by a linear one function:

$f=\left(u_{x}\right)=\sigma_{0}-k u_{x}$

$k$ - coefficient of hardness of the soil; $\sigma_{0}-$ soil pressure is in a state of rest.

The resultant effort is the sum of effective pressure on the fence on both sides of the supporting wall. It can be represented in the form of two graphs of effective soil pressure on the retaining wall from the soil (1) and from the pit (2), depending on the horizontal displacement of the wall (Fig. 4). 


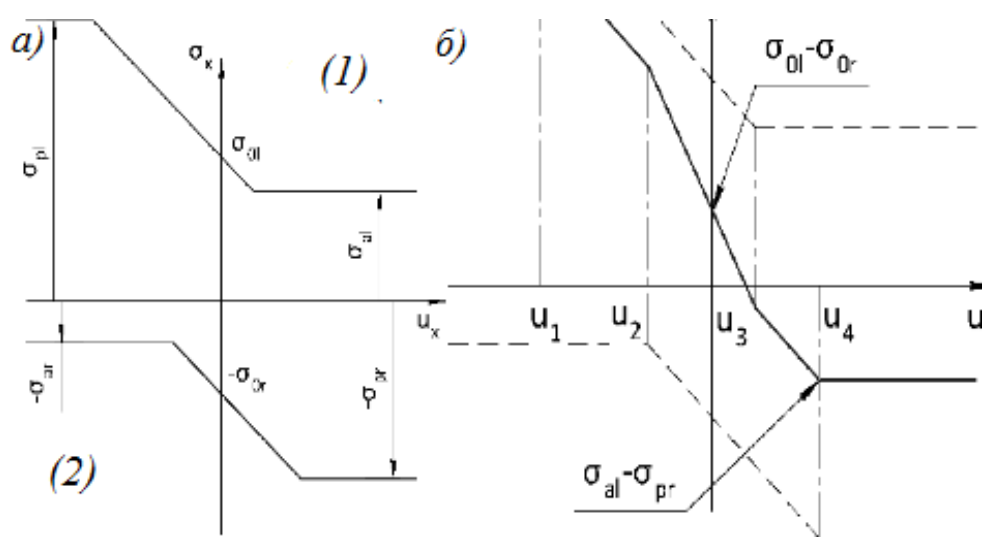

Fig. 4. Graph of the dependence of soil pressure on the movement of the supporting wall: a) the diagrams of effective pressures on the fence to the left and right; б) the diagram of the resulting pressure on the fence

To describe the individual sections of the chart, we use the equation (2), (3), (4), (7), adding indexes " $l$ " and " $R$ " for terms relating to the left and right sides of the fence. In the case where the wall on both sides is surrounded by a soil array, $\sigma_{x}\left(z, u_{x}\right)$ will look like:

$$
\sigma_{x}\left(z, u_{x}\right)=\left\{\begin{array}{lr}
\sigma_{p}^{l}(z)-\sigma_{a}^{r}\left(z-h_{k}\right) & u_{x} \leq u_{1} \\
\sigma_{0}^{l}(z)-\sigma_{0}^{r}\left(z-h_{k}\right)-u_{x} k^{l}, & u_{1}<u_{x}<u_{2} \\
\sigma_{0}^{l}(z)-\sigma_{0}^{r}\left(z-h_{k}\right)-u_{x}\left(k^{l}+k^{r}\right), & u_{2} \leq u_{x} \leq u_{3} \\
\sigma_{a}^{l}(z)-\sigma_{0}^{r}\left(z-h_{k}\right)-u_{x} k^{r}, & u_{3}<u_{x}<u_{4} \\
\sigma_{a}^{l}(z)-\sigma_{p}^{r}\left(z-h_{k}\right), & u_{4} \leq u_{x}
\end{array}\right.
$$

If you separately consider the resulting pressure on the fence before laying $\left(z \leq h_{k}\right)$, then the expression (7) will look like:

$$
\sigma_{x}\left(u_{x}\right)=\left\{\begin{array}{lr}
\sigma_{p}^{l}(z), & u_{x} \leq u_{1} \\
\sigma_{0}^{l}(z)-u_{x} k^{l}, & u_{1}<u_{x}<u_{3} \\
\sigma_{a}^{l}(z), & u_{3} \leq u_{x}
\end{array}\right.
$$

The basis for the expressions (2), (3), (4) in (8) and (9) we obtain:

$$
\begin{gathered}
\sigma_{x}\left(z, u_{x}\right)=\left\{\begin{array}{lc}
\lambda_{p}^{l} \gamma z+c \lambda_{p c}^{l}, & u_{x} \leq u_{1} \\
\lambda_{0}^{l} \gamma z-k^{l} u_{x}, & u_{1}<u_{x}<u_{3} \\
\lambda_{a}^{l} \gamma z-c \lambda_{a c}^{l}, & u_{3} \leq u_{x}
\end{array}\right. \\
\sigma_{x}\left(z, u_{x}\right)=\left\{\begin{array}{lr}
\lambda_{p}^{l} \gamma z-\lambda_{a}^{l} \gamma\left(z-h_{k}\right)+c \lambda_{p c}^{l}+c \lambda_{a c}^{r}, & (10) \\
\lambda_{0}^{l} \gamma z-\lambda_{a}^{l} \gamma\left(z-h_{k}\right)+c \lambda_{a c}^{l}-u_{x} k^{l}, & u_{x} \leq u_{1} \\
\lambda_{0}^{l} \gamma z-\lambda_{0}^{l} \gamma\left(z-h_{k}\right)-u_{x}\left(k^{l}+k^{r}\right), & u_{2} \leq u_{x} \leq u_{3} \\
\lambda_{a}^{l} \gamma z-\lambda_{0}^{l} \gamma\left(z-h_{k}\right)-c \lambda_{a c}^{l}-u_{x} k^{r}, & u_{3}<u_{x}<u_{4} \\
\lambda_{a}^{l} \gamma z-\lambda_{p}^{l} \gamma\left(z-h_{k}\right)-c \lambda_{a c}^{l}-c \lambda_{p c}^{r}, & u_{4} \leq u_{x}
\end{array}\right.
\end{gathered}
$$

There is a large number of methods for determining the coefficients of active and passive soil pressure in a state of rest, depending on the angle of internal friction $\varphi$ of the soil and the friction angle on the contact with the fence $\delta$.

In the conditions of the horizontal surface of the filling and the absence of slopes of the design faces to the vertical, the coefficient of active horizontal pressure becomes the form:

$$
\lambda_{a}=\frac{\cos ^{2}(\varphi)}{\left[1+\sqrt{\frac{\sin (\delta+\varphi) \sin (\varphi)}{\cos \delta}}\right]^{2}}
$$

The coefficient of passive horizontal pressure takes the form of:

$$
\lambda_{p}=\frac{\cos ^{2}(\varphi)}{\left[1-\sqrt{\frac{\sin (\delta+\varphi) \sin (\varphi)}{\cos \delta}}\right]^{2}}
$$

For a complete description of all the components included in (10), it is necessary to determine $\lambda_{a c}$ and $\lambda_{p c}$. According to [4-7], the values are determined as follows: 


$$
\begin{aligned}
& \lambda_{a c}=\frac{1}{\tan (\varphi)} \cdot\left[1-\lambda_{a}\right] \\
& \lambda_{p c}=\frac{1}{\tan (\varphi)} \cdot\left[\lambda_{p}-1\right]
\end{aligned}
$$

With expressions $(11)-(15)$, the pressure of the soil can be completely described on a flexible vertical retaining wall, depending on the displacement. Calculation of the fence of the pit using the considered model "manual" method is very labor-intensive. This calculation scheme is numerically implemented in the GeoWall software complex [8-10].

As an example, we consider the one- off calculation supporting fence type "The Wall in the Moon ".

Output data:

- thickness of reinforced concrete wall of $620 \mathrm{~mm}$;

- mark of the bottom of the pit $\mathrm{H}_{\mathrm{k}}=16.4 \mathrm{~m}$;

- concrete of the class B 25, fittings A-I (A240) diameter of $25 \mathrm{~mm}$;

- phased development of the foundation pit (5 stages);

- installation of 4 tiers of shootings;

- engineering-geological conditions are taken as the basis of the project line of the subway on the housing estate Vynogradar.

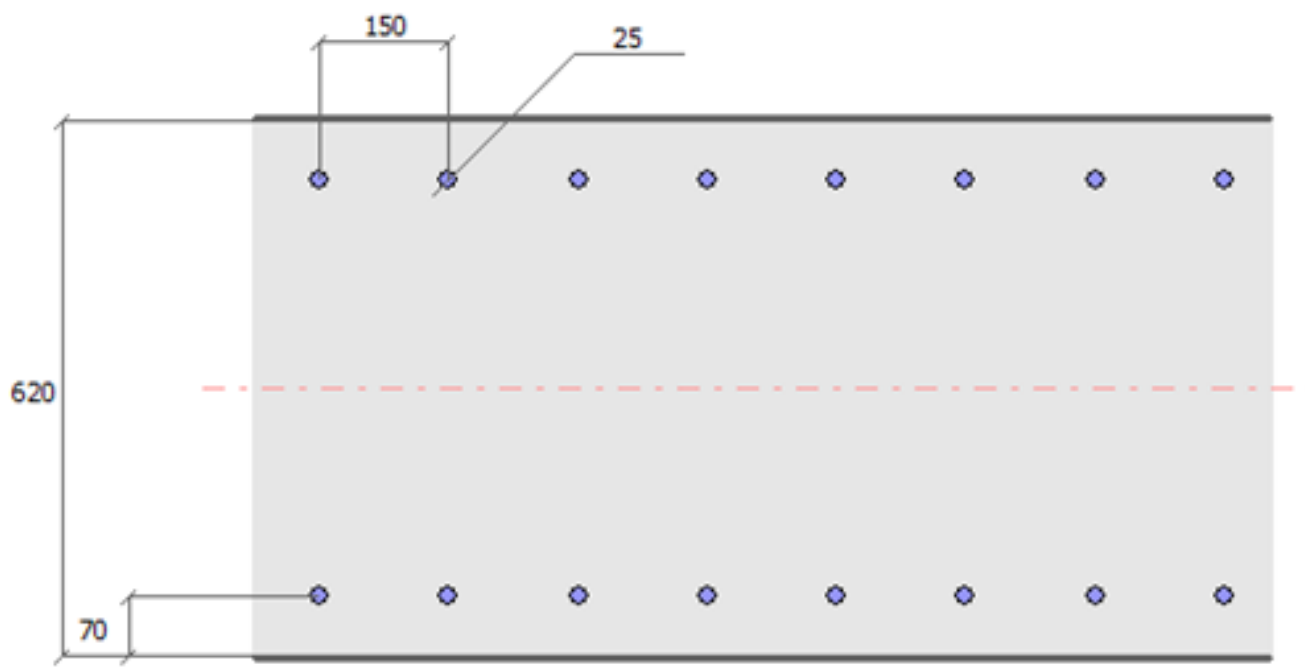

Fig. 5. The design of the wall

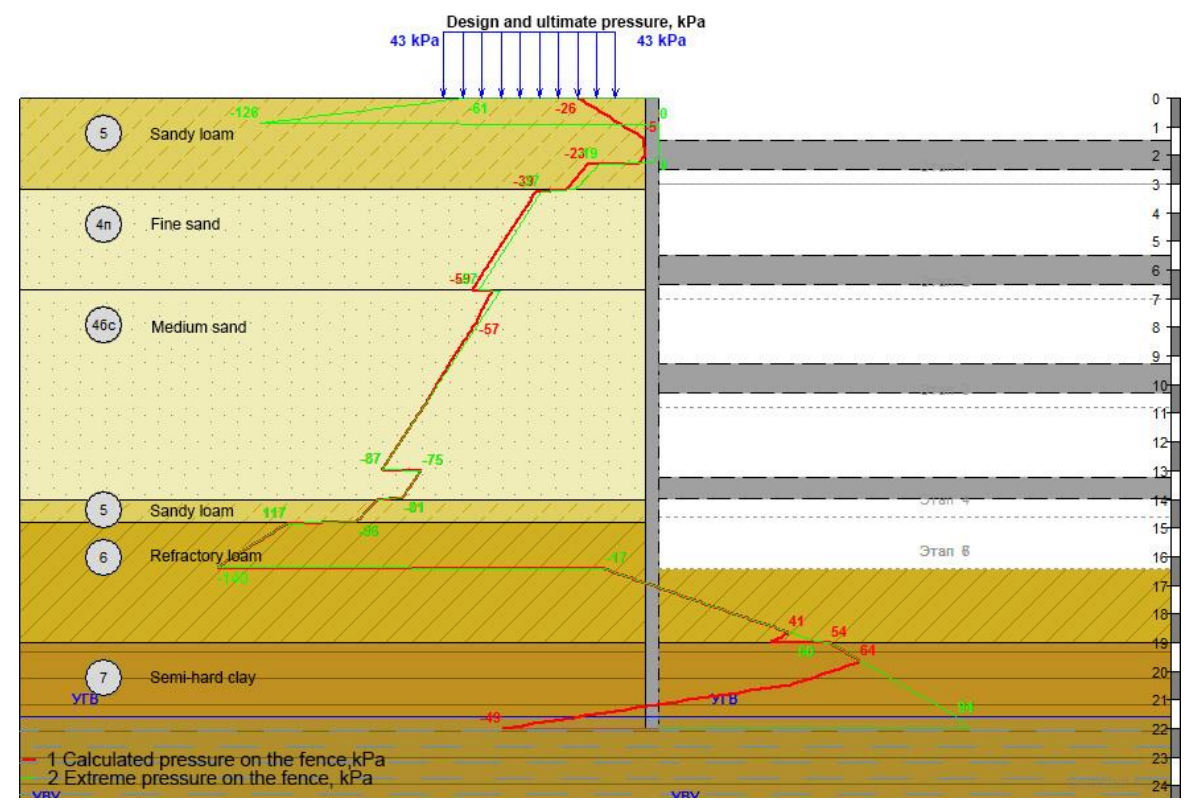

Fig. 6. Estimated and permissible pressure at 5th stage 


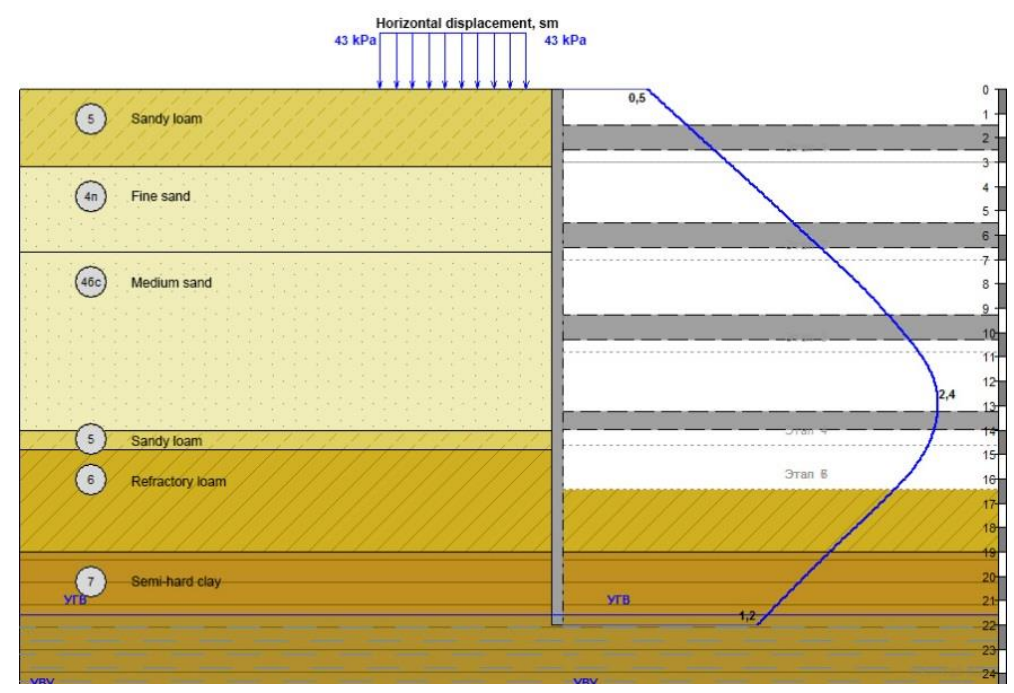

Fig. 7. Horizontally moving at 5 th stage $(0.5,0.4,1.2 \mathrm{~cm})$

The maximum passive pressure from the side of the supporting soil is $-1144.4 \mathrm{kPa}$ Maximum resting pressure from the supporting soil

Maximum active pressure from retained soil $-398.34 \mathrm{kPa}$

Maximum effective pressure from retained soil

Maximum bending moment

Maximum horizontal movement $-226.39 \mathrm{kPa}$

Maximum cross- sectional force

$-275.39 \mathrm{kPa}$

Factor of stock in mortgages

The minimum stockade in a metal

$-357 \mathrm{kNm} / \mathrm{m}$

Minimum reserve factor in concrete

$-3.3 \mathrm{~cm}$

$-196 \mathrm{kN} / \mathrm{m}$

Estimated longitudinal force of the 1st tier spacing

Estimated longitudinal force the spacing of the 2nd tier

Estimated longitudinal force the spacing of the 3rd tier

Estimated longitudinal force four-tier spacing

$-1.2$

$-2.1$

$-1.3$

$-307 \mathrm{kN}$

$-876 \mathrm{kN}$

$-1240 \mathrm{kN}$

- $1176 \mathrm{kN}$

\section{The graph of the pressure dependence}

from the depth of the pit on stage 1

$\sigma, \mathbf{k P a}$

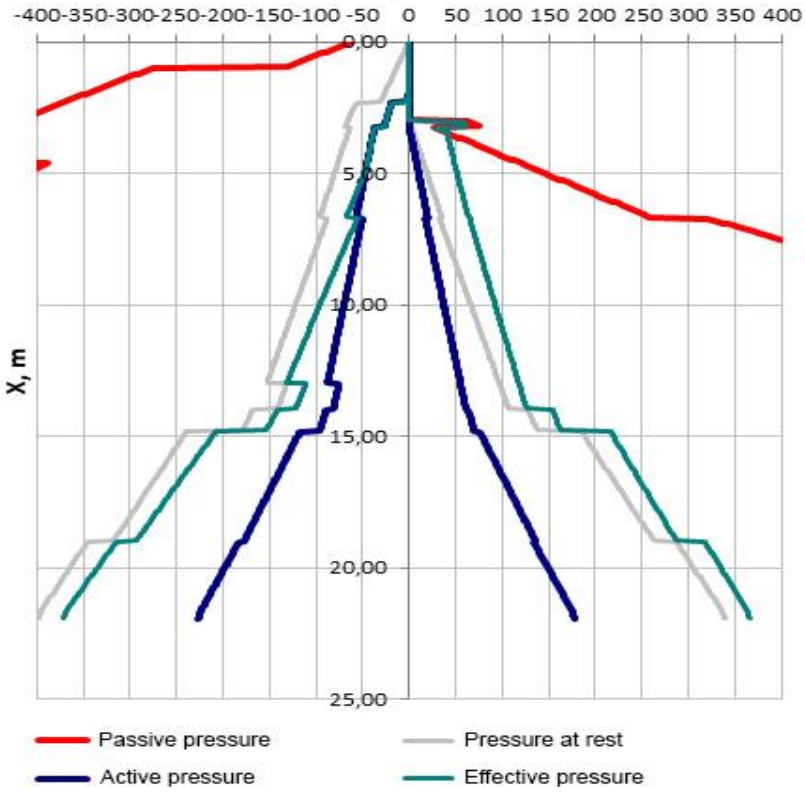

Fig. 8. Pressure on stage 1 of the device 
The graph of the pressure dependence

from the depth of the pit on stage 5

$$
\sigma, \mathbf{k P a}
$$



Fig 9. Pressure on the 5th stage of the installation

\section{Horizontal displacement}

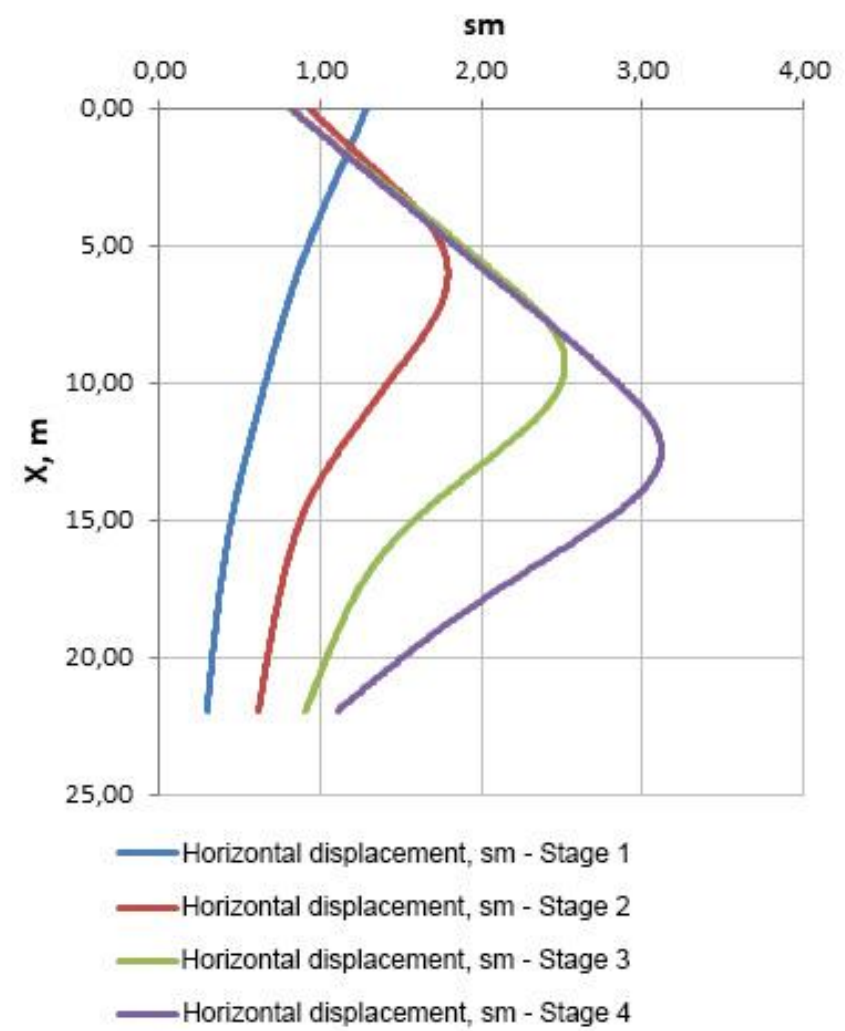

Fig 10. Horizontally moving in 4 stages, depending on the depth of development 
Fig. 8, 9 shows that the value of effective horizontal pressure $\sigma_{\mathrm{x}}$ on each side lies between the boundary values is active $\sigma_{\mathrm{a}}$ and passive $\sigma_{\mathrm{p}}$. Due to not large displacement of pressure $\sigma_{x}$ left on in some areas the height of the fence is more active $\sigma_{\mathrm{a}}$ pressure at $\sigma_{x}$ to the right at a small depth from the bottom of the pit reaches the limit value $\sigma_{\mathrm{p}}$, but on the other $\sigma_{x} \epsilon\left(\sigma_{0}, \sigma_{\mathrm{p}}\right)$. In case of pressure on the right $\sigma_{x}$ across the depths will reach the value of passive pressure $\sigma_{\mathrm{p}}$ its resign itself to loosening fasteners resistance [8].

To determine the displacement of flexible retaining walls, you can use a numerical method, for example, by the finite element method, taking into account the above techniques. According to the graph of the horizontal displacement Fig. 10, it can be concluded that with increasing depth of development of the pit deviation of the supporting structure increase, and have a dependent character [8].

\section{Список використаної літератури:}

1. Костюченко М.М. Механіка грунтів : навч. посіб. / М.М. Костюченко. - К. : Київський університет, 2013.- 116 c.

2. Баклашов И.В. Механика подземных сооружений и конструкции крепей / И.В. Баклашов, Б.А. Картозия. - М. : Студент, 2012. - 543 с.

3. Клейн Г.К. Расчет подпорных стен / Г.К. Клейн. - М. : Рипол Классик, 2013. - 200 с.

4. Ильчев B.A. Справочник геотехника. Основания, фундаменты и подземные сооружения / В.А. Ильчев, P.A. Мангушев. - М. : АСВ. -728 c.

5. Парамонов В.Н. Экспериментальная проверка применимости некоторых нелинейных моделей грунта для расчета ограждений котлованов / В.Н. Парамонов, К.В. Сливец // Вестник Томского государственного архитектурно-строительного университета. - № 4. - 2008. - С. 139-145.

6. Настанова з проектування котлованів для улаштування фундаментів і заглиблених споруд : ДСТУ-Н Б В.2.132:2014. - К. : Укрархбудінформ, 2014.

7. Diersch H.-J.G. Fellow finite element subsurface flow and transport simulation system / H.-J.G. Diersch. - Berlin :WASY Ltd, 2004. - 168 p.

8. Кучер С.A. Обгрунтування підтримуючої конструкції кріплення котловану при будівництві станції метрополітену : дисертація : 184 «Гірництво» / С.А. Кучер. - К., 2018. -137 с.

9. Кучер С.A. Закрепление склонов в разных инженерно-геологических условиях города Киева / C.A. Кучер, C.В. Зайченко, В.В. Вапничная // Перспективи розвитку будівельних технологій : матеріали 11-ї міжнародної науково-практичної конференції молодих вчених, аспірантів і студентів, присвячена 80-ти річчю пам'яті Івана Степановича Новосільцева. - Дніпро, 2017. - С. 30-35.

10. Кучер С.А. Оцінка стійкості схилів 3 використанням рlaxis на прикладі міста Києва / С.А. Кучер, В.В. Вапнічна // Тези дев'ятої Всеукраїнської науково-технічної конференції студентів, аспірантів і молодих вчених «Наукова весна». - Дніпро, 2018. - С. 20-21.

\section{References:}

1. Kostyuchenko, M.M. (2013), Mekhanika hruntiv, navchal'nyy posibnyk, Kyyivs'kyi universytet, Kyiv, $116 \mathrm{p}$

2. Baklashov, I.V. and Kartoziya, B.A. (2012), Mekhanika podzemnykh sooruzheniy i konstruktsii krepey, Student, M., 543 p.

3. Kleyn, G.K. (2013), Raschet podpornykh sten, Ripol Klassik, M., 200 p.

4. Il'chev, V.A. and Mangushev, R.A. (2014), Spravochnik geotekhnika. Osnovaniya, fundamenty $i$ podzemnyye sooruzheniya, ACB, M., 728 p.

5. Paramonov, V.N. and Slivets, K.V. (2008), «Eksperimental'naya proverka primenimosti nekotorykh nelineynykh modeley grunta dlya rascheta ograzhdeniy kotlovanov», Vestnik Tomskogo gosudarstvennogo arkhitekturnostroitel'nogo universiteta, No. 4, pp. 139-145.

6. Minregion Ukrai'ny (2014), DSTU-N B V.2.1-32: Nastanova z proektuvannya kotlovaniv dlya ulashtuvannya fundamentiv i zahlyblenykh sporud, Ukrarhbudinform, Ukrai'na.

7. Diersch, H.-J.G. (2004), Fellow finite element subsurface flow and transport simulation system, WASY Ltd, Berlin, 168 p.

8. Kucher, S.A. (2018), Obgruntuvannya pidtrymuyuchoyi konstruktsiyi kriplennya kotlovanu pry budivnytstvi stantsiyi metropolitenu, Dissertation, spec. 184 Girnyctvo, Kyi'v, 137 p.

9. Kucher, S.A., Zaichenko, S.V. and Vapnichnaia, V.V. (2017), «Zakrepleniye sklonov v raznykh inzhenernogeologicheskikh usloviyakh goroda Kiyeva», Perspektyvy rozvytku budivel'nykh tekhnolohiy, materialy 11-i' mizhnarodnoyi naukovo-praktychnoyi konferentsiyi molodykh uchenykh, aspirantiv i studentiv, prysvyachena 80-ty richchyu pam'yati Ivana Stepanovycha Novosyl'tseva, Dnipro, pp. 30-35.

10. Kucher, S.A. and Vapnichna, V.V. (2018), «Otsinka stiykosti skhyliv z vykorystannyam plaxis na prykladi mista Kyyeva», Tezy dev"yatoyi vseukrayins'koyi naukovo-tekhnichnoyi konferentsiyi studentiv, aspirantiv i molodykh uchenykh «Naukova vesna», Dnipro, pp. 20-21.

Вапнічна Вікторія Вікторівна - кандидат технічних наук, доцент, кафедра геоінженерії, Національний технічний університет України «Київський політехнічний інститут імені Ігоря Сікорського».

ORCID: https://orcid.org/0000-0003-3938-4358

Шевчук Наталія Анатоліївна - кандидат технічних наук, доцент, кафедра економіки і підприємництва, Національний технічний університет України «Київський політехнічний інститут імені Ігоря Сікорського».

ORCID: http://orcid.org/0000-0003-0355-9793 